\title{
Potential local regulatory functions of inhibins, activins and follistatin in the ovary
}

\author{
Philip G. Knight and Claire Glister \\ School of Animal and Microbial Sciences, The University of Reading, Whiteknights, \\ Reading RG6 6AJ, UK
}

\begin{abstract}
The changing pattern of granulosa cell expression of inhibin/activin subunits and follistatin during follicle development and their differential regulation by extrinsic and intraovarian factors supports evidence from functional studies, mostly in vitro, that these proteins have important roles in folliculogenesis, oocyte maturation and corpus luteum function. Gonadal inhibins function as negative feedback hormones to regulate the synthesis and secretion of pituitary $\mathrm{FSH}$, a key determinant of follicle development, but there is little supportive evidence for a peripheral endocrine role for ovary-derived activins or follistatin in this regard. However, activins and follistatin are expressed in numerous other tissues, including anterior pituitary, and they are firmly implicated as local intrapituitary regulators of FSH secretion. Intraovarian actions of granulosa cell-derived activins include the promotion of granulosa cell proliferation and upregulation of FSH receptors, P450arom, oestrogen synthesis, granulosa cell LH receptors and enhancement of oocyte maturation. Through its activin-binding role, follistatin can reverse each of these activin-induced responses. In addition to their endocrine feedback role, granulosaderived inhibins can sensitize theca cells to $\mathrm{LH}$, thereby enhancing the production of androgens, an essential requirement for follicular oestrogen synthesis. Activins can oppose this effect and suppress thecal androgen production. Granulosa cells overproduce inhibin $\alpha$ subunit precursor relative to $\beta \mathrm{A} / \beta \mathrm{B}$ subunit precursors and evidence indicates that different parts of the inhibin $\alpha$ subunit precursor have intrinsic biological activities distinct from inhibin $\alpha \beta \mathrm{A} / \mathrm{B}$ dimer, and serve as additional local modulators of follicle and corpus luteum function.
\end{abstract}

Growth and development of primordial follicles through to ovulatory status is associated with marked proliferation, recruitment and differentiation of somatic cells and with changes in oocyte size and morphology, reflecting both nuclear and cytoplasmic maturation. Most follicles (> 99.9\%) never reach ovulatory status, but undergo atresia at some point along this extended developmental pathway. The mechanisms that regulate the ordered recruitment of quiescent primordial follicles into the growing pool have not been determined, but are likely to involve locally produced growth and differentiation factors, some of which emanate from the oocyte itself, including growth and differentiation factor 9 (GDF-9) and bone morphogenetic protein 15 (BMP-15) (Elvin et al., 2000). Follicle development up to the late preantral and early antral stages occurs independently of pituitary gonadotrophins despite the fact that $\mathrm{FSH}$ receptor mRNA transcripts are detectable in granulosa cells from as early as the primary follicle stage (Findlay and Drummond, 1999). Experiments involving

Email:p.g.knight@reading.ac.uk hypophysectomy, gonadotrophin suppression and selective replacement therapy have shown that gonadotrophic support is obligatory for the continued growth of follicles beyond the small-medium antral stage. Transient increases in FSH secretion during the ovarian cycle are responsible for initiating recurrent waves of antral follicle development (approximately 10-20 follicles per wave or cohort). By a mechanism that has yet to be fully resolved, but which probably involves subtle differences in their responsiveness to $\mathrm{FSH}$ and $\mathrm{LH}$, one (or several, depending on species) of these follicles is selected for continued growth to ovulatory size (referred to as the 'dominant follicle'), whereas the other 'subordinate follicles' cease growing and are destined for atresia.

\section{Locally produced growth factors in the ovary}

In addition to extrinsic regulation by pituitary gonadotrophins and metabolic hormones, evidence has emerged to support the involvement of various locally produced growth factors as co-regulators of folliculogenesis (Fig. 1). The list of factors implicated so far includes insulin-like growth factors (IGFs), 


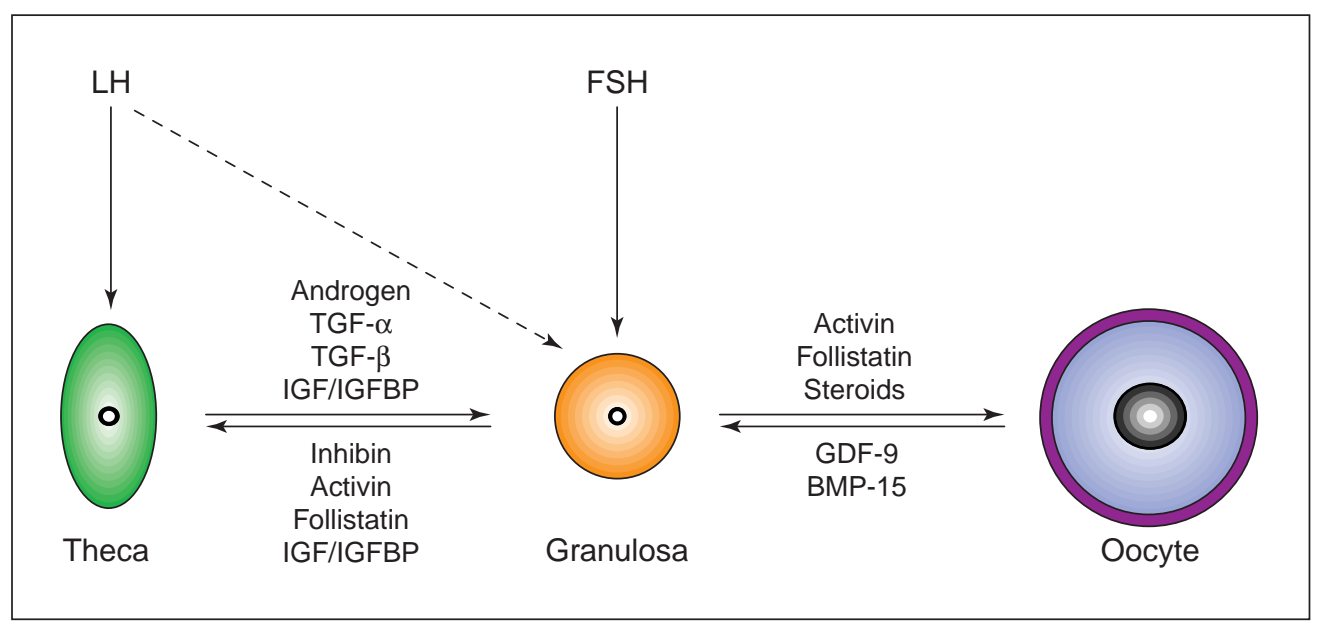

Fig. 1. Simplified schematic representation of the three principal types of cell of the ovarian follicle, indicating the primary extrinsic factors supporting follicle development as well as several intrafollicular factors likely to be involved in cell-cell communication between theca cells, granulosa cells and the oocyte. BMP-15: bone morphogenetic protein 15; GDF-9: growth and differentiation factor 9; IGF: insulin-like growth factor; IGFBP: insulin-like growth factor-binding proteins.

IGF-binding proteins (IGFBPs), epidermal growth factor (EGF), transforming growth factor $\alpha$ (TGF- $\alpha$ ), fibroblast growth factor (FGF), transforming growth factor $\beta$ (TGF- $\beta$ ), GDF-9, BMP-15, inhibins, activins and follistatins (Webb et al., 1999; Elvin et al., 2000). This article will focus on the last three factors only. It should be pointed out that intraovarian expression of a particular growth factor, or its receptor, may itself be gonadotrophin-dependent, in which case it may be considered to serve as a local mediator of gonadotrophin action. Alternatively, a growth factor may exert a regulatory action by modulating cellular responsiveness to gonadotrophins (for example by upregulating FSH receptors). For instance, a growth factor that augments FSH responsiveness would promote further follicle growth, whereas one that attenuates FSH responsiveness might precipitate atresia.

As emphasized by Findlay (1993), a number of issues should be addressed before a substance can be classed as having an autocrine or paracrine role: (i) whether local production of the factor can be demonstrated (for example expression of its mRNA, immunochemical localization within cells or net synthesis in vivo or in vitro); (ii) whether its production is modulated by other factors (for example systemic signals or other locally produced factors); (iii) whether specific receptors are present and whether the factor elicits a demonstrable cellular response, either on the same type of cell that secreted it (autocrine action) or on neighbouring cells (paracrine action); (iv) whether the action of the factor is regulated locally (for example by a binding protein, formation from a pro-hormone, enzymatic degradation or cellular uptake); (v) whether evidence obtained in vivo is consistent with the proposed local autocrine-paracrine action of the factor shown in vitro.
These points are worth keeping in mind when considering the evidence supporting intraovarian roles of inhibins, activins and follistatin. Apart from the final and possibly most challenging point, that relating to confirmation of findings in vitro in 'whole animal' models, these conditions have largely been met.

\section{Inhibins, activins and follistatins}

\section{Basic features}

Inhibins and activins are disulphide-linked dimeric glycoproteins belonging to the TGF- $\beta$ superfamily. Inhibins are dimers of a unique $\alpha$ subunit linked to either a $\beta A$ or $\beta B$ subunit to generate inhibin $A(\alpha-\beta A)$ or inhibin $B(\beta-\beta B)$ (Fig. 2). Dimerization of $\beta$ subunits alone gives rise to three forms of activin referred to as activin $A(\beta A-\beta A)$, activin $A B$ $(\beta A-\beta B)$ and activin $B(\beta B-\beta B)$. The $\alpha, \beta A$ and $\beta B$ subunits are derived from three different precursor polypeptides encoded by distinct genes (Ying, 1988). Differential posttranslational processing, particularly of the $\alpha$ precursor, gives rise to several different size variants of inhibin A and B. Follistatin, a cysteine-rich monomeric glycoprotein encoded by a single gene, is structurally unrelated to the TGF- $\beta$ superfamily, but is linked functionally through its role as a high-affinity binding protein for activins. There are several different isoforms of follistatin due to alternative mRNA splicing and post-translational modification.

Inhibins, activins and follistatins were first identified in ovarian follicular fluid through their ability to modulate the secretion of FSH from pituitary gonadotrophs in vitro: inhibins and follistatin suppress FSH secretion, whereas 


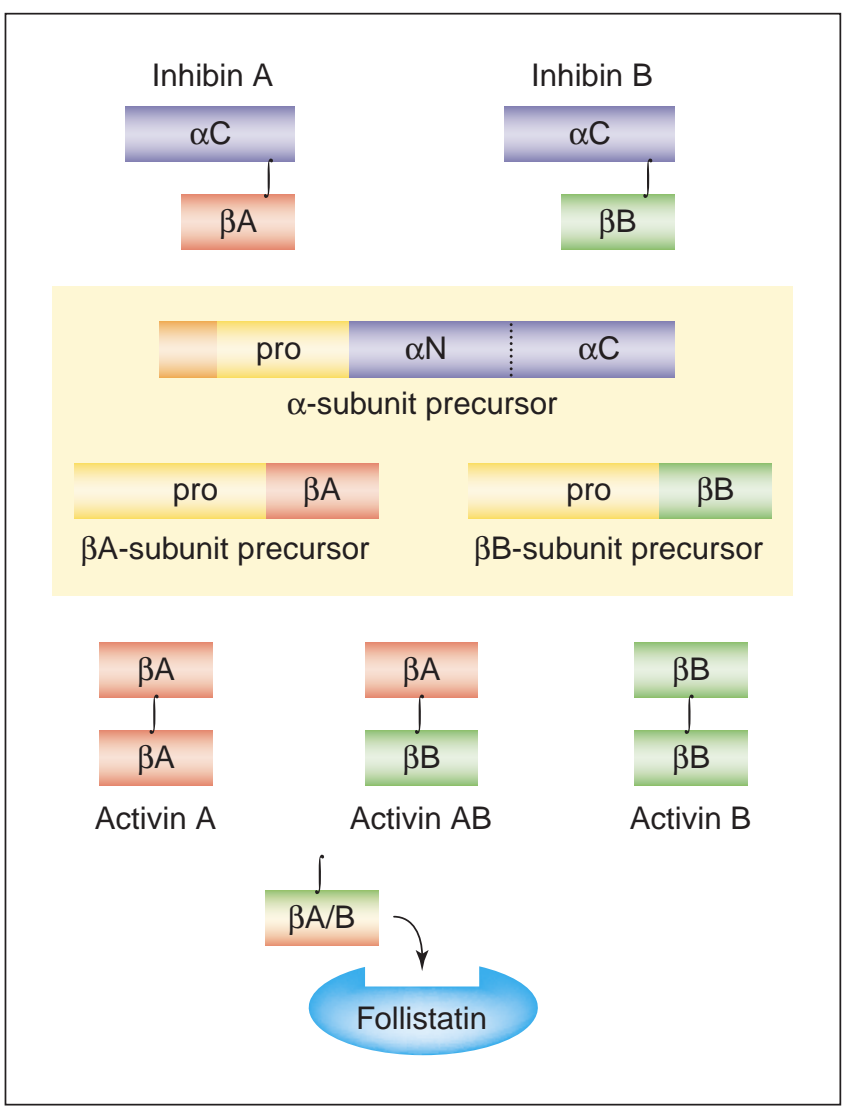

Fig. 2. Basic molecular structures of the different isoforms of inhibin and activin. Inhibins $A$ and $B$ are disulphide-linked heterodimers of an $\alpha$ subunit and one of two alternative $\beta$ subunits $(\beta A$ and $\beta B)$, whereas activins $(A, A B, B)$ are homo- or heterodimers of two $\beta$ subunits $(\beta A \beta A, \beta A \beta B, \beta B \beta B)$. Each subunit is derived from a separate precursor molecule. Follistatin is structurally dissimilar to inhibins and activins and functions as a high affinity activin-binding protein.

activins enhance FSH secretion. Although a long-loop negative feedback role for ovarian inhibins in the regulation of FSH secretion is now well established in both sexes (Knight, 1996; Mather et al., 1997; de Kretser et al., 2000), it is unlikely that activins of ovarian origin exert endocrine effects on the pituitary. Rather, activins are produced by, and subserve local regulatory roles in, a diverse range of tissues including the anterior pituitary (Besecke et al., 1997). Moreover, it appears that all of the activin present in the peripheral circulation is tightly bound to follistatin, which effectively neutralizes its biological activity and prevents it from acting on distant target tissues (Woodruff, 1998). Follistatin also binds to inhibin, but with much lower affinity, and this binding does not appear to neutralize inhibin bioactivity.

\section{Receptors}

Activin receptors were cloned and characterized in the early 1990s (reviewed by Zimmerman and Mathews, 1996).
Both type I and II activin receptors are expressed by granulosa cells, theca cells and oocytes, consistent with local intraovarian actions on these types of cell (Eramaa et al., 1995; Mather et al., 1997; Sidis et al., 1998). Inhibin-specific receptors have not yet been isolated or characterized, although recent progress has been made towards this goal (Woodruff, 1999). It was recently discovered that inhibin binds (via its $\alpha$ subunit) with high affinity to the type III TGF- $\beta$ receptor, betaglycan (Lewis et al., 2000), and that this binding markedly enhances the binding of inhibin (via its $\beta$ subunit) to the type II activin receptor. Therefore, at least some of the activin-opposing actions of inhibin probably involve interference with activin binding to its type II receptor, which prevents activin-induced heteromerization of type I and type II receptors, a requirement for triggering the activin-dependent intracellular signalling cascade (Lebrun et al., 1997). A further possibility indicated by this recent discovery is that free inhibin $\alpha$ subunit could facilitate activin action by competing with inhibin for binding to betaglycan; this would reduce the interaction of inhibin with the type II activin receptor. In other words, free inhibin $\alpha$ subunit could function as an inhibin antagonist and a physiological agonist of activin. This hypothesis remains to be evaluated.

\section{Intraovarian actions}

Compelling evidence, mainly from studies in vitro on isolated follicles, granulosa cells, theca cells and oocytes supports the notion that activins, follistatin and, to a lesser degree, inhibins synthesized by follicular granulosa cells exert local autocrine-paracrine actions to modulate follicle growth, gonadotrophin responsiveness, steroidogenesis, oocyte maturation, ovulation and corpus luteum function (Fig. 3). Studies in vivo involving transgenic 'knockout' mice deficient in inhibin/activin $\alpha$ or $\beta$ subunits, activin receptors or follistatin (reviewed by Nishimori and Matzuk, 1996) have also provided vital clues about the critical roles of these proteins in ovarian function. This evidence will be considered in more detail in the following sections.

\section{Autocrine-paracrine effects on granulosa cells}

Studies in vitro support a local intrafollicular role of activin in promoting granulosa cell proliferation and differentiation. Activin-induced proliferation has been observed with cultured rat granulosa cells from both small and large follicles (Li et al., 1995; Miro and Hillier, 1996) and with human granulosa lutein cells (Rabinovici et al., 1990). In addition, targeted deletion of the inhibin $\alpha$ subunit gene in mice, which leads to overproduction of activin, is associated with uncontrolled proliferation of granulosa cells and ovarian tumour development (Matzuk et al., 1992). In contrast, in 'knockout' mice lacking activin type IIB receptors, follicle development was arrested at an early antral stage, consistent with a key role for activin in granulosa cell proliferation and differentiation (Nishimori and Matzuk, 1996). However, it should be noted that plasma FSH concentrations were markedly suppressed in 


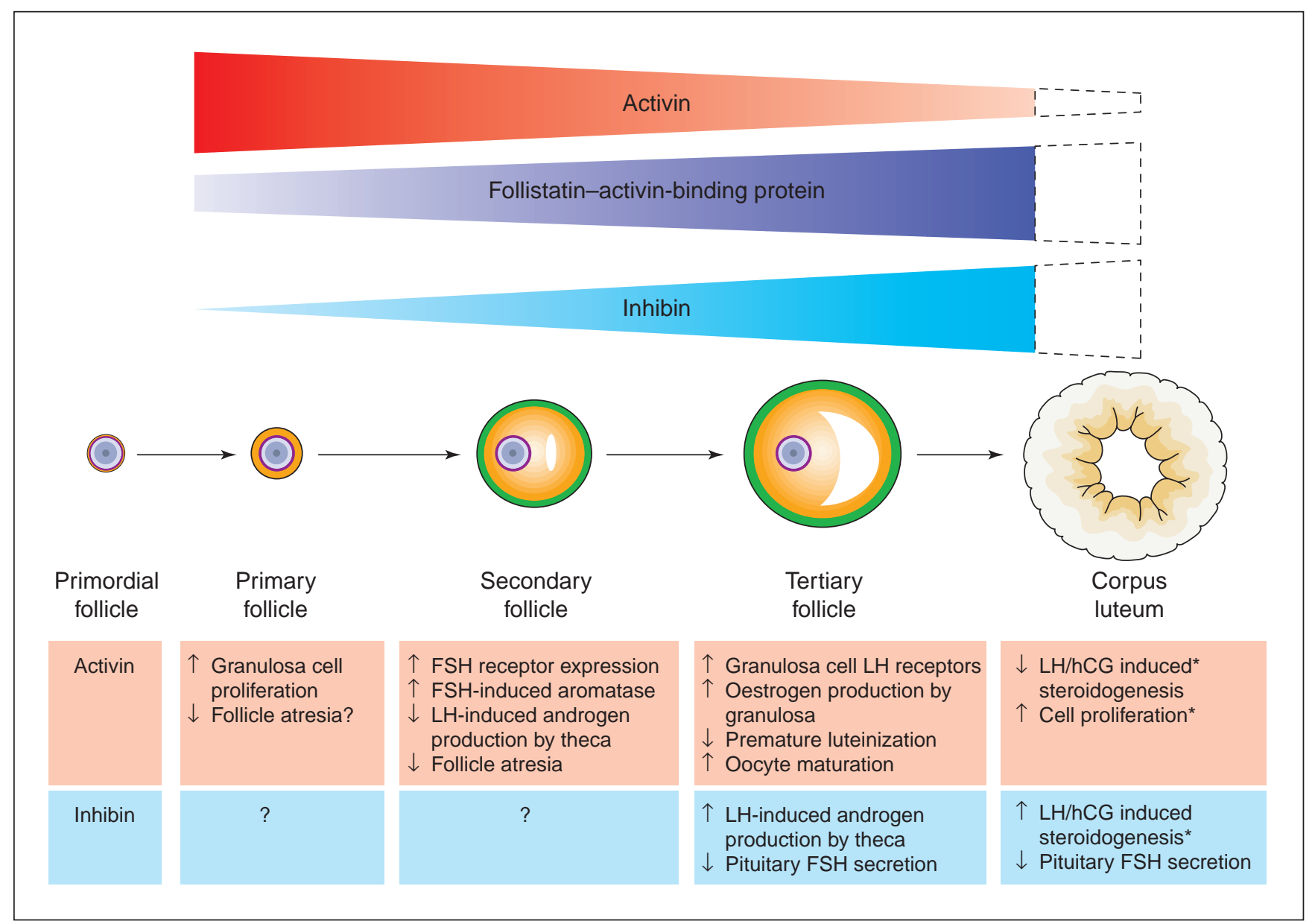

Fig. 3. Schematic diagram relating presumed changes in expression in granulosa cells of inhibin, activin and follistatin at different stages of follicle development to their putative regulatory functions at the intraovarian and peripheral level. Through its activin-binding capacity, follistatin can neutralize the biological activity of activin. Note that expression of inhibin A and follistatin is maintained in primate corpus luteum, but declines after ovulation in other species. Asterisks indicate roles restricted to primate species.

these activin receptor-deficient mice, making it difficult to distinguish between an indirect pituitary FSH-mediated and direct intraovarian action of activin receptor deletion. Acquisition of granulosa cell responsiveness to $\mathrm{FSH}$ is considered a pivotal event in the life history of a follicle. The discovery that activin can promote FSH receptor expression on undifferentiated rat granulosa cells (Hasegawa et al., 1988; Xiao et al., 1992) is particularly significant since this could explain how a follicle at the late preantral to early antral stage progresses from a gonadotrophin-independent to a gonadotrophin-dependent stage of development. Given the ability of follistatin to bind and neutralize activin, the proposed action of activin to promote $\mathrm{FSH}$ receptor expression in small follicles would operate most successfully in the absence of follistatin. Evidence that undifferentiated rat granulosa cells express relatively little follistatin in comparison with cells from more developmentally advanced follicles (Shimasaki et al., 1989; Nakatani et al., 1991) supports this concept. Moreover, indirect evidence from in situ hybridization studies on primate ovaries implies that follicles in the early stage of development preferentially synthesize activin rather than inhibin (Schwall et al., 1990; Yamoto et al., 1992). However, analysis of the capacity of follicles at defined developmental stages to produce each assembled form of inhibin/activin dimer (activin $A, A B, B B$, inhibin $A$, inhibin B) and follistatin protein will ultimately be required to confirm that there is a functional excess of activin over inhibin and follistatin in follicles at the early stage of development.

Once granulosa cells have acquired functional FSH receptors, their proliferation and differentiation would be driven mainly by FSH (and LH at the preovulatory stage) but modulated by other extrinsic (for example insulin, growth hormone, leptin?) and locally produced factors having both stimulatory (for example oestradiol, IGF, activin) and inhibitory (for example TGF- $\alpha$, IGFBPs, follistatin) actions (Greenwald and Roy, 1994; Webb et al., 1999). A recent in vivo study in cattle aimed to define the biochemical characteristics of growing follicles that are destined to 
achieve dominance (Mihm et al., 2000). Although no differences in follicular fluid concentrations of inhibin A, activin $A$ or follistatin were evident, the study showed that by day 3 of the ovarian cycle the future dominant follicle had a lower intrafollicular concentration of IGFBP-4 and a higher concentration of oestradiol compared with cohort follicles of similar size. It is suggested that reduced intrafollicular IGFBP-4 makes more 'free' IGF available to amplify FSH responsiveness, and thus confers a selective advantage on this follicle.

Studies in vitro in a range of species support a role for activin in the regulation of granulosa cell steroidogenesis, although the nature of this involvement appears to vary with the stage of follicular development. Studies involving non-luteinized granulosa cells from both immature and preovulatory marmoset follicles showed that activin can enhance basal and gonadotrophin-stimulated P450arom activity (Hillier and Miro, 1993). This finding is consistent with other studies on rat and bovine granulosa cells showing that activin can enhance P450arom activity and oestradiol production while inhibiting progesterone secretion (Hutchinson et al., 1987; Miro et al., 1991; Shukovski et al., 1991). These findings indicate that intrafollicular activin may have a role in delaying the onset of atresia and luteinization. Studies on cells from more developmentally advanced follicles (human granulosa lutein cells) revealed that activin has an anti-steroidogenic action, inhibiting basal and gonadotrophin-stimulated P450scc expression, progesterone secretion, P450arom activity and oestradiol production (Cataldo et al., 1994; Eramaa et al., 1995). Follistatin reverses the effect of activin on progesterone secretion by human granulosa lutein cells (Cataldo et al., 1994), whereas it has no effect in the absence of activin. Studies in rats have shown that follistatin can also suppress P450arom activity and inhibin production and increase progesterone secretion (Xiao et al., 1992). These observations imply a role for follistatin in promoting follicle atresia (associated with decreased oestradiol and inhibin production and increased progesterone) or luteinization, depending on the developmental stage reached. The finding that transgenic mice overexpressing follistatin show arrested follicle development in vivo (Guo et al., 1998) is broadly consistent with the above evidence obtained in vitro.

Evidence for an autocrine role of inhibin in modulating granulosa cell steroidogenesis is more controversial. An early indication that inhibin can suppress FSH-induced P450arom activity in cultured rat granulosa cells (Ying et al., 1986) was not substantiated by later studies in rats (Hutchinson et al., 1987; Sugino et al., 1988) and humans (Rabinovici et al., 1994). However, Miro and Hillier (1992) noted a small inhibin-induced decline in FSH-induced P450arom activity in marmoset granulosa cells obtained from immature follicles. Infusion of inhibin into the ovarian artery of ewes bearing an autotransplanted ovary reduced ovarian output of both androstenedione and oestradiol (Campbell and Scaramuzzi, 1996). However, this finding is difficult to interpret since plasma FSH concentrations were also suppressed, raising the possibility of a pituitarymediated rather than direct ovarian action of the infused inhibin.

Granulosa cells express much more inhibin $\alpha$ subunit than $\beta \mathrm{A} / \beta \mathrm{B}$ subunits (Ying et al., 1988; Knight, 1996) and several forms of monomeric inhibin $\alpha$ subunit have been identified in follicular fluid; these include full-length $\alpha$ precursor and a number of post-translational cleavage products including pro- $\alpha \mathrm{C}, \alpha \mathrm{C}$ and $\alpha \mathrm{N}$. None of the free $\alpha$ forms isolated so far possesses classical inhibin-like bioactivity (that is the ability to suppress pituitary FSH secretion), but one study indicates that the full-length $\alpha$ precursor can compete with $\mathrm{FSH}$ for binding to its receptor and so attenuate the action of FSH on granulosa cells (Schneyer et al., 1991). Thus, the intrafollicular concentration of free inhibin $\alpha$ subunit precursor could be another factor in determining how FSH responsive a particular follicle is. Further support for an intrafollicular role of inhibin $\alpha$ subunit comes from a study in which sheep were actively immunized against the $\alpha C$ region of the $\alpha$ subunit precursor (Tannetta et al., 1998). Immunized sheep showed enhanced follicle development even though plasma gonadotrophin concentrations were similar to those in control sheep. Moreover, follicular concentrations of activin A, but not follistatin, were much higher in immunized sheep, consistent with the notion that activin upregulates granulosa cell responsiveness to FSH. This observation is reminiscent of the aforementioned finding (Matzuk et al., 1992) that inhibin $\alpha$ 'knockout' mice show raised activin concentrations and uncontrolled granulosa cell proliferation.

Another post-translational product of the $\alpha$ subunit precursor, termed the $\alpha \mathrm{N}$ fragment, may have a local intrafollicular role to facilitate ovulation. Active immunization of ewes against $\alpha \mathrm{N}$ had no detectable effect on reproductive hormones in the circulation but reduced litter size and disrupted ovulation as indicated by a reduced number of eggs in the oviducts and a greater incidence of luteinized or unruptured follicles and corpora lutea (Findlay et al., 1994). It was subsequently shown that the lowered fertility of $\alpha \mathrm{N}$ immunized ewes was associated with restricted tissue remodelling and reduced matrix metalloproteinase 2 activity in follicular fluid at the time of expected ovulation (Russell et al., 1995).

\section{Paracrine effects on theca cells}

A characteristic feature of a dominant preovulatory follicle is its capacity to synthesize and secrete much greater amounts of oestrogen than its subordinates, which requires a high P450arom activity in granulosa cells and an adequate supply of P450arom substrate (androgen). In most species, granulosa cells lack P450c17 and are thus unable to synthesize their own androgen; they are therefore dependent on androgens synthesized by the surrounding theca cells. Studies in vitro on human (Hillier, 1991), rat 
(Hsueh et al., 1987) and bovine (Wrathall and Knight, 1995) theca cells have shown that inhibin A (a product of gonadotrophin-responsive oestrogen-active granulosa cells) can enhance $\mathrm{LH}$-induced androgen production. Incubation of whole rat follicles (Smyth et al., 1993) with neutralizing antibodies to inhibin reduced androgen secretion, consistent with a positive action of endogenous inhibin on thecal androgen production. This action of inhibin could be an important intrafollicular positive feedback mechanism for ensuring that the preovulatory follicle obtains sufficient substrate to keep pace with increasing oestrogen synthesis.

Treatment of human, rat and bovine theca cells with activin reduces $\mathrm{LH}$-induced androgen production and opposes the action of inhibin (Hsueh et al., 1987; Hillier, 1991; Wrathall and Knight, 1995). In bovine theca cells, oestradiol upregulates thecal androgen production (Wrathall and Knight, 1995), and this effect was also reduced by activin. Moreover, the inhibitory effects of activin on both $\mathrm{LH}$ - and oestradiol-induced androgen secretion were reversed by follistatin, consistent with its role as an activin-binding protein. Collectively, the findings from studies in vitro indicate that granulosa cell-derived inhibins and activins have mutually opposing paracrine actions to modulate thecal androgen synthesis. The effect of activin is, in turn, subject to regulation by follistatin produced locally.

Hillier (1991) proposed that in immature follicles, which synthesize very little oestrogen, thecal androgen synthesis is also low due to a relative excess of activin over inhibin and follistatin (that is, high 'activin tone', low 'inhibin tone'). However, as a dominant follicle approaches preovulatory status, increasing expression of inhibin and follistatin in granulosa cells, possibly accompanied by decreasing expression of activin (that is, low 'activin tone', high 'inhibin tone') upregulate thecal androgen secretion and thereby ensure that the granulosa cells receive an adequate supply of P450arom substrate to match the increasing demand for oestradiol synthesis (Fig. 4). This hypothesis is supported by histological evidence of developmental changes in expression of inhibin/activin subunit and follistatin during folliculogenesis and by observed changes in intrafollicular concentrations of inhibins and activin A during follicular development (Magoffin and Jakimiuk, 1998). The latter authors showed that concentrations of activin $\mathrm{A}$ in follicular fluid were similar in human follicles ranging from 5 to $20 \mathrm{~mm}$ in diameter, whereas inhibin $\mathrm{A}$ and inhibin $\mathrm{B}$ concentrations increased markedly with follicle size. Unfortunately, intrafollicular follistatin concentrations were not measured by Magoffin and Jakimiuk (1998), so it was not possible to assess the relative amount of 'free' (presumably bioavailable) activin present at different stages.

\section{Paracrine effects on the oocyte}

As in the early stages of follicle development, it is evident that factors secreted by the oocyte continue to influence the surrounding somatic cells as follicle maturation proceeds.

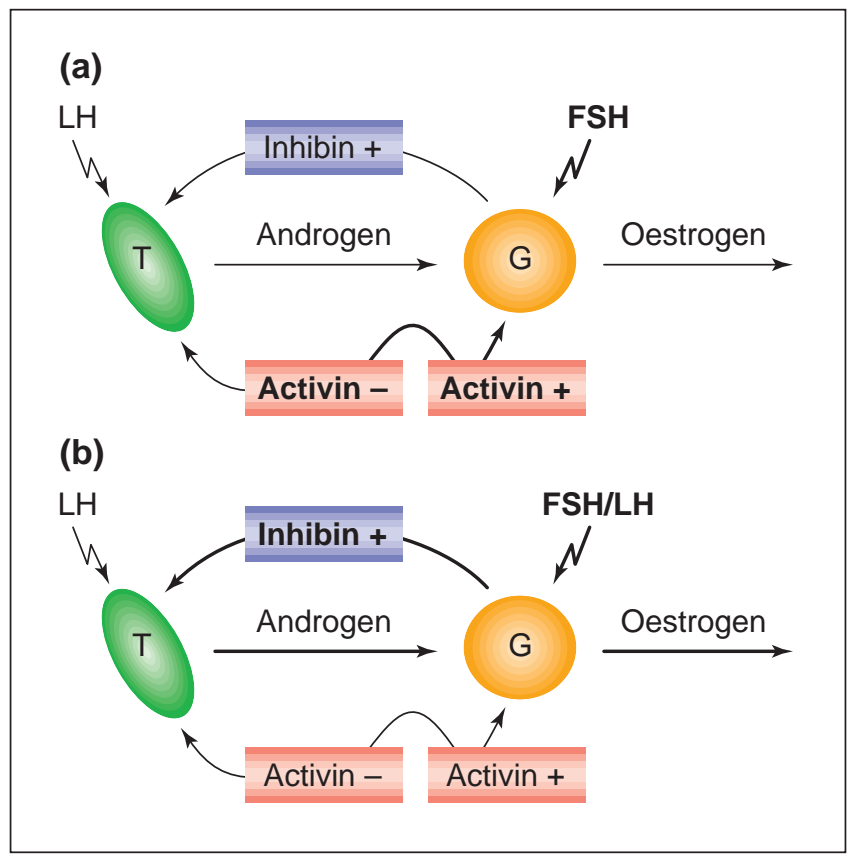

Fig. 4. Hypothetical roles of inhibin and activin in the control of follicular oestrogen synthesis. Stimulatory and inhibitory actions are denoted by + and - , respectively. (a) Early follicular phase. Granulosa cells (G) of immature follicles express high concentrations of activin but lower concentrations of its binding protein, follistatin. 'Free' activin enhances FSH-induced P450arom activity, simultaneously suppressing androgen synthesis by theca cells $(\mathrm{T})$ at a time when follicular oestrogen synthesis is still low. (b) Late follicular phase. Granulosa cells of the preovulatory follicle respond to stimulation by $\mathrm{FSH}$ and $\mathrm{LH}$ with increased production of inhibin, paralleling the preovulatory increase in P450arom activity. Inhibin acts locally to promote LH-stimulated androgen synthesis by theca interna. As inhibin production increases (possibly in association with reduced production of activin and increased production of follistatin), a positive feedback loop is created through which thecal androgen synthesis is amplified to sustain oestrogen synthesis in the granulosa cell layer. (Adapted from Hillier, 1991.)

Conversely, factors produced by somatic cells contribute to the ordered cytoplasmic and nuclear maturation of the oocyte and to the maintenance of 'meiotic arrest' until a preovulatory $\mathrm{LH}$ surge or follicle atresia ensues, or the oocyte is removed from its follicular environment for in vitro maturation (Greenwald and Roy, 1994; Eppig, 1996).

Cumulus granulosa cells express high levels of inhibin/ activin $\alpha, \beta A, \beta B$ subunit and follistatin mRNA and protein (Roberts et al., 1993; Sidis et al., 1998; see Fig. 5a) and oocytes express activin receptors (Cameron et al., 1994; Sidis et al., 1998). These observations reinforce evidence from functional in vitro studies in several species that cumulus-derived activins affect nuclear and cytoplasmic maturation of oocytes. For instance, activin accelerates in vitro meiotic maturation of oocytes in monkeys (Alak et al., 
(a)
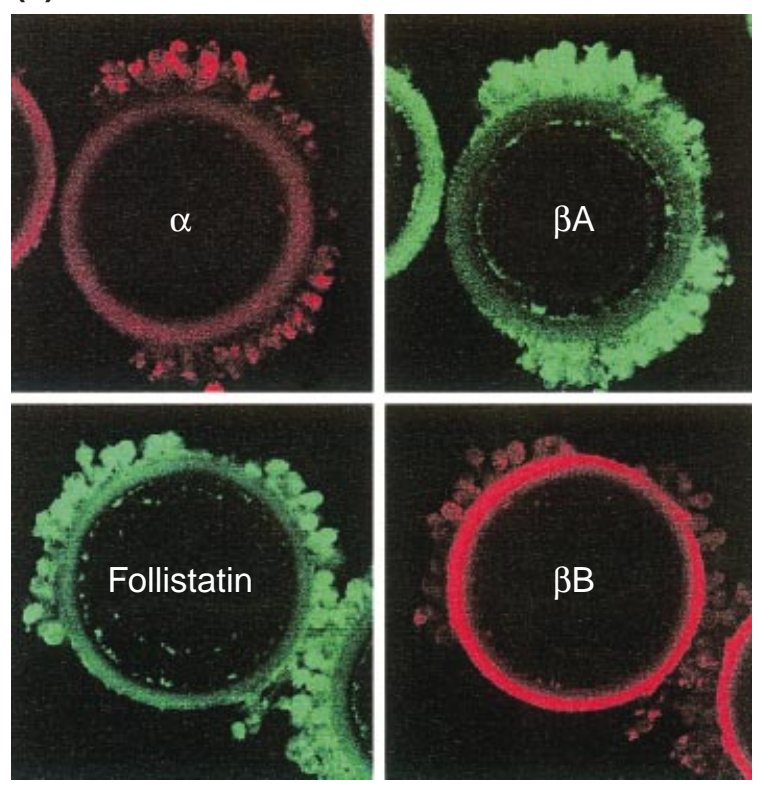

(b)

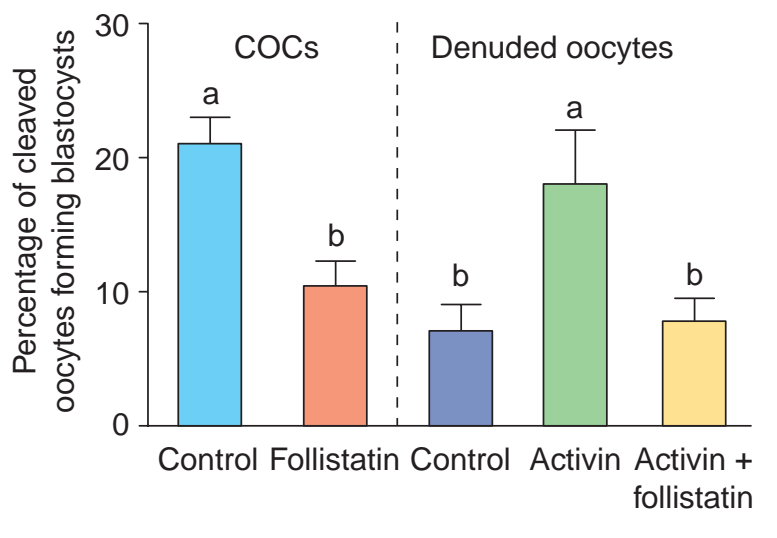

Fig. 5. Evidence that activins and follistatin secreted by bovine cumulus cells during in vitro oocyte maturation modulate oocyte developmental competence. (a) Immunohistochemical localization of inhibin $\alpha$ (red) inhibin/activin $\beta B$ (green), $\beta B$ (red) and follistatin (green) protein in cumulus cells surrounding partially denuded bovine oocytes (C. C. Silva and P. G. Knight, unpublished). (b) Follistatin reduces blastocyst yield from cumulus-enclosed oocytes (COCs) to a value similar to that observed with cumulusfree (denuded) oocytes. Activin enhances blastocyst yield from cumulus-free oocytes to a value similar to that for cumulusenclosed oocytes. The effect of activin was blocked by follistatin. (Data re-plotted from Silva and Knight, 1998.)

1996), rats (Sadatsuki et al., 1993) and humans (Alak et al., 1998), an effect that was inhibited by follistatin. Exposure of denuded or cumulus-enclosed bovine oocytes to activin-A did not affect cleavage rate after IVF but increased their developmental competence to form blastocysts (Silva and
Knight, 1998). Conversely, follistatin reduced oocyte developmental competence and neutralized the effect of both endogenous and exogenous activin, consistent with its functional role as an activin-binding protein (Fig. 5b).

Evidence implicating inhibin as a potential modulator of oocyte maturation is less consistent, although it has been reported that inhibin can suppress the spontaneous maturation division of cumulus-enclosed and denuded oocytes from immature rats (O et al., 1989). However, in conflict with other reports, activin had no effect in this study. In a recent study on cumulus-enclosed bovine oocytes (Silva et al., 1999), free inhibin $\alpha$ subunit (pro- $\alpha \mathrm{C}$ ), but not inhibin $\mathrm{A}$, was shown to reduce oocyte developmental competence. Moreover, addition of antibodies against $\alpha$ subunit enhanced oocyte developmental competence, an observation consistent with an inhibitory role of free inhibin $\alpha$ subunit, which is known to be produced in large amounts by cumulus cells. Irrespective of their physiological relevance to normal oocyte maturation in vivo, these observations indicate ways of improving the outcome of assisted reproduction techniques that involve manipulation of oocytes in vitro.

\section{Autocrine-paracrine actions in the corpus luteum}

Expression of inhibin/activin subunits and follistatin in granulosa cells is downregulated after the $\mathrm{LH}$ surge and is low in the corpus luteum of most species examined. However, in primates, with the exception of $\beta B$ subunit, the level of expression is maintained after ovulation (Yamoto et al., 1991; Roberts et al., 1993). The corpus luteum becomes a significant source of inhibin $A$ in particular and circulating concentrations peak in the mid-luteal phase of the human cycle (Muttukrishna et al., 1994). These observations point to potential autocrine-paracrine actions of inhibin-related molecules in the regulation of luteal function in primates.

A role for endogenous inhibin (or its free $\alpha$ subunit) in promoting luteal progesterone production is indicated by the finding that addition of $\alpha$ inhibin antibody to marmoset luteal cells reduced hCG-induced progesterone secretion (Webley et al., 1994). In contrast, activin has been shown to promote proliferation of cultured human granulosa lutein cells and decrease basal and hCG-induced progesterone secretion (Rabinovici et al., 1990; Di Simone et al., 1994); the latter response is reversed by follistatin (Cataldo et al., 1994). Activin also suppresses progesterone secretion by cultured monkey luteal cells (Brannian et al., 1992). Given that expression of follistatin is upregulated by hCG in granulosa lutein cells (Tuuri et al., 1994), follistatin could be an important component of the gonadotrophin-dependent luteal support mechanism.

\section{Conclusions}

As discussed in this review, there is a wealth of evidence to support the view that inhibins, activins and follistatin function as intraovarian regulatory molecules involved in follicle cell proliferation, steroidogenesis, oocyte 


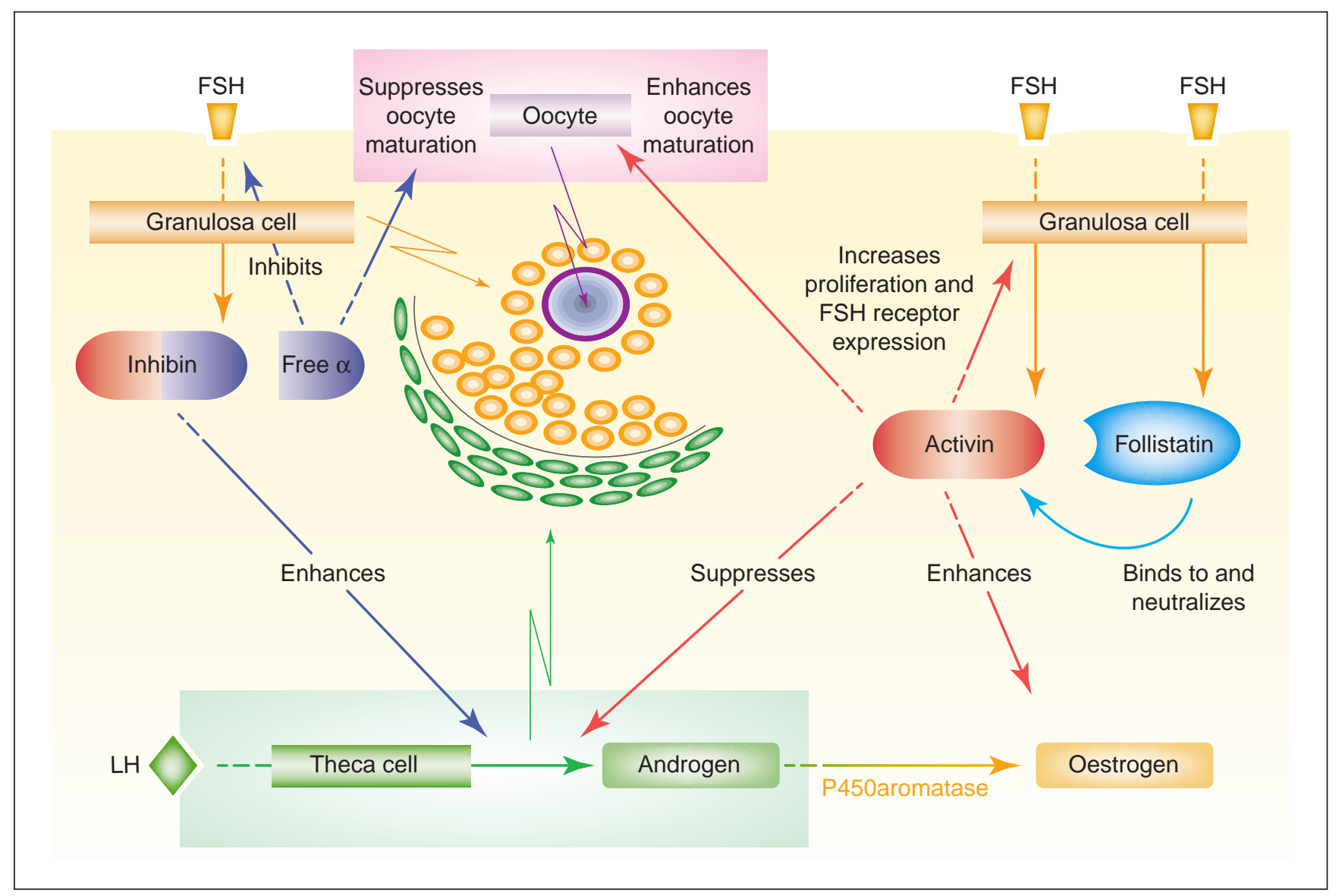

Fig. 6. Schematic diagram summarizing potential intrafollicular roles of inhibins, activins and follistatin. All three proteins are synthesized and secreted by granulosa cells in an FSH-responsive manner. Local actions of activins include promotion of granulosa cell proliferation, FSH receptor expression, P450arom expression and oestrogen production, inhibition of $\mathrm{LH}$-induced androgen production by thecal cells and enhancement of oocyte maturation; follistatin can block each of these activin-induced responses. Inhibins can enhance LH-induced androgen production by thecal cells but evidence that they have direct modulatory actions on granulosa cells is contradictory. There is some evidence that 'free' inhibin $\alpha$ subunit can function as an FSH-binding inhibitor; it may also exert a suppressive action on oocyte maturation.

maturation and corpus luteum function (see Fig. 6 for summary). However, it cannot be overemphasized that nearly all of this evidence has accrued from in vitro experiments on isolated cells and tissues. A key challenge now is to devise appropriate in vivo models to verify that these putative roles do indeed have physiological relevance in whole animals. The creation of transgenic mouse mutants lacking functional copies of the genes encoding inhibin/ activin $\alpha, \beta A, \beta B$ subunits, activin receptor subtypes and follistatin (for a review see Nishimori and Matzuk, 1996) has undoubtedly yielded major insights into the functional roles of these peptides, particularly in early mammalian development. However, this approach is not ideally suited to the in vivo analysis of gene function in particular organ systems at later developmental stages (for example cyclic ovarian function in an adult mammal); the challenge remains to develop improved whole animal experimental models for this purpose.

\section{References}

Key references are identified by asterisks.

Alak BM, Smith GD, Woodruff TK, Stouffer RL and Wolf DP (1996) Enhancement of primate oocyte maturation and fertilization in vitro by inhibin A and activin A Fertility and Sterility 66 646-653

Alak BM, Coskun S, Friedman CI, Kennard EA, Kim MH and Seifer DB (1998) Activin A stimulates meiotic maturation of human oocytes and modulates granulosa cell steroidogenesis in vitro. Fertility and Sterility 701126-1130

Besecke LM, Guender MJ, Sluss PA, Polak AG, Woodruff TK, Jameson JL, Bauer-Dantoin AC and Weiss J (1997) Pituitary follistatin regulates activin-mediated production of follicle-stimulating hormone during the rat estrous cycle Endocrinology 138 2841-2848

Brannian J, Woodruff T, Mather J and Stouffer RL (1992) Activin-A inhibits progesterone production by macaque luteal cells in culture Journal of Clinical Endocrinology and Metabolism 75 756-761

Cameron V, Nishimura E, Mathews L, Lewis K, Sawchenco P and Vale W (1994) Hybridization histochemical localization of activin receptor subtypes in rat brain, pituitary, ovary and testis Endocrinology 134 799-808

Campbell BK and Scaramuzzi RJ (1996) The effect of ovarian arterial 
infusion of human recombinant inhibin and bovine follicular fluid on ovarian hormone secretion by ewes with an autotransplanted ovary Journal of Endocrinology 149 531-540

Cataldo NA, Rabinovici J, Fujimoto VY and Jaffe RB (1994) Follistatin antagonizes the effects of activin-A on steroidogenesis in human luteinizing granulosa cells Journal of Clinical Endocrinology and Metabolism 79 272-277

de Kretser DM, Meinhardt A, Meehan T, Phillips DJ, O'Bryan MK and Loveland KA (2000) The roles of inhibin and related peptides in gonadal function Molecular and Cellular Endocrinology 161 43-46

Di Simone ND, Ronsisvalle E, Lanzone A, Caruso A, Petraglia F and Mancuso S (1994) Effect of activin A on progesterone synthesis in human luteal cells Fertility and Sterility $\mathbf{6 2}$ 1157-1161

Elvin JA, Yan C and Matzuk MM (2000) Oocyte-expressed TGF-beta superfamily members in female fertility Molecular and Cellular Endocrinology 159 1-5

Eppig J (1996) Coordination of nuclear and cytoplasmic oocyte maturation in eutherian mammals Reproduction Fertility and Development 8 485-489

Eramaa M, Hilden K, Tuuri T and Ritvos O (1995) Regulation of inhibin/activin subunit messenger ribonucleic acids (mRNAs) by activin $A$ and expression of activin receptor mRNAs in cultured human granulosa-luteal cells Endocrinology 136 4382-4389

Findlay J, Russel D, Doughton B, Tsonis C, Borchers C and Forage R (1994) Effect of active immunization against the amino-terminal peptide $(\alpha \mathrm{N})$ of the alpha $43 \mathrm{kDa}$ subunit of inhibin ( $\alpha 43)$ on fertility of ewes Reproduction Fertility and Development 6 265-267

Findlay JK (1993) An update on the roles of inhibin, activin and follistatin as local regulators of folliculogenesis Biology of Reproduction 48 15-23

Findlay JK and Drummond AE (1999) Regulation of the FSH receptor in the ovary Trends in Endocrinology and Metabolism 10 183-188

Greenwald GS and Roy SK (1994) Follicular development and its control. In The Physiology of Reproduction 2nd Edn pp 629-724 Eds E Knobil, and JD Neill. Raven Press Ltd, New York

Guo Q, Kumar TR, Woodruff T, Hadsell LA, DeMayo FJ and Matzuk MM (1998) Overexpression of mouse follistatin causes reproductive defects in transgenic mice Molecular Endocrinology 12 96-106

Hasegawa Y, Miyamoto K, Abe Y, Nakamura T, Sugino H, Eto Y, Shibai H and Igarashi M (1988) Induction of follicle-stimulating hormone receptor by erythroid differentiation factor on rat granulosa cells Biochemical and Biophysical Research Communications 156 668-674

Hillier SG (1991) Regulatory functions for inhibin and activin in human ovaries Journal of Endocrinology 131 171-175

Hillier SG and Miro F (1993) Inhibin, activin and follistatin: potential roles in ovarian physiology Annals of the New York Academy of Sciences 687 29-38

*Hsueh AJW, Dahl KD, Vaughan J, Tucker E, Rivier J and Bardin CW (1987) Heterodimers and homodimers of inhibin subunits have different paracrine action in the modulation of luteinizing hormone-stimulated androgen biosynthesis Proceedings National Academy of Sciences USA 84 5082-5086

Hutchinson LA, Findlay JK, deVos FL and Robertson DM (1987) Effects of bovine inhibin, transforming growth factor $\beta$ and bovine activin-A on granulosa cell differentiation Biochemical and Biophysical Research Communications 146 1405-1412

Knight PG (1996) Roles of inhibins, activins and follistatin in the female reproductive system Frontiers in Neuroendocrinology 17 476-509

Lebrun JJ, Chen Y and Vale W (1997) Receptor serine kinases and signaling by activins and inhibins. In Inhibin, Activin and Follistatin Regulatory Functions in System and Cell Biology pp 1-20 Eds T Aono, H Sugino and W Vale. Springer Serono Symposia, USA

Lewis KA, Gray PC, Blount AL, MacConnell LA, Wiater E, Bilezikjian LM and Vale W (2000) Betaglycan binds inhibin and can mediate functional antagonism of activin signaling Nature $\mathbf{4 0 4} 411-414$

*Li R, Phillips DM and Mather JP (1995) Activin promotes ovarian follicle development in vitro. Endocrinology 136 849-856

Magoffin DA and Jakimiuk AJ (1998) Inhibin A, inhibin B and activin A in the follicular fluid of regularly cycling women Human Reproduction 12 1714-1719
Mather JP, Moore A and Li RH (1997) Activins, inhibins and follistatins: further thoughts on a growing family of regulators Proceedings of the Society of Experimental and Biological Medicine 215 209-222

*Matzuk M, Ginegold M, Su J, Hsueh A and Bradley A (1992) $\alpha$-inhibin is a tumour-suppressor gene with gonadal specificity in mice Nature $\mathbf{3 6 0}$ 313-319

Mihm M, Austin EA, Good TEM, Ireland JLH, Knight PG, Roche JF and Ireland JJ (2000) Identification of potential intrafollicular factors involved in selection of dominant follicles in heifers Biology of Reproduction 63 811-819

Miro F and Hillier SG (1992) Relative effects of activin and inhibin on steroid hormone synthesis in primate granulosa cells Journal of Clinical Endocrinology and Metabolism 75 1556-1561

Miro F and Hillier SG (1996) Modulation of granulosa cell deoxyribonucleic acid synthesis and differentiation by activin Endocrinology 137 464-468

Miro F, Smyth CD and Hillier SG (1991) Development-related effects of recombinant activin on steroid synthesis in rat granulosa cells Endocrinology 129 3388-3394

Muttukrishna S, Fowler PA, Groome NP, Mitchell GG, Robertson WR and Knight PG (1994) Serum concentrations of dimeric inhibin during the spontaneous human menstrual cycle and after treatment with exogenous gonadotrophin Human Reproduction 9 1634-1642

Nakatani A, Shimasaki S, DePaolo LV, Erickson GF and Ling N (1991) Cyclic changes in follistatin messenger ribonucleic acid and its protein in the rat ovary during the oestrous cycle Endocrinology 129 603-611

*Nishimori K and Matzuk MM (1996) Transgenic mice in the analysis of reproductive development and function Reviews of Reproduction 1 203-212

O WS, Robertson DM and de Kretser DM (1989) Inhibin as an oocyte meiotic inhibitor Molecular and Cellular Endocrinology 62 307-311

Rabinovici J, Spencer S and Jaffe R (1990) Recombinant human activin-A promotes proliferation of human luteinized preovulatory granulosa cells in vitro. Journal of Clinical Endocrinology and Metabolism 71 1396-1398

Rabinovici J, Spencer S, Doldi N and Jaffe R (1994) Localization and actions of activin in the human ovary and adrenal gland. In Frontiers in Endocrinology Vol. 3 Inhibin and Inhibin-Related Proteins pp 191-198 Eds H Burger, J Findlay, D Roberston, D de Kretser and F Petraglia. AresSerono Symposia, Rome

*Roberts VJ, Barth S, El-Roeiy A and Yen SSC (1993) Expression of inhibin/activin subunits and follistatin messenger ribonucleic acids and proteins in ovarian follicles and the corpus luteum during the human menstrual cycle Journal of Clinical Endocrinology and Metabolism 77 $1402-1410$

Russell DL, Salamonsen LA and Findlay JK (1995) Immunization against the $\mathrm{N}$-terminal peptide of the inhibin $\alpha_{43}$-subunit $(\alpha \mathrm{N})$ disrupts tissue remodeling and the increase in matrix metalloproteinase-2 during ovulation Endocrinology 136 3657-3664

Sadatsuki M, Tsutsumi O, Yamada R, Muramatsu M and Taketani Y (1993) Local regulatory effects of activin and follistatin on meiotic maturation of rat oocytes Biochemical and Biophysical Research Communications $196388-395$

Schneyer AL, Sluss SP, Whitcomb RW, Martin KA, Sprengel R and Crowley WF (1991) Precursors of $\alpha$-inhibin modulate folliclestimulating hormone receptor binding and biological activity Endocrinology 129 1987-1999

Schwall RH, Mason AJ, Wilcox JN, Basset SG and Zeleznik AJ (1990) Localization of inhibin/activin subunit mRNAs within the primate ovary Molecular Endocrinology 4 75-79

Shimasaki S, Koga M, Buscaglia M, Simmons D, Bicsak T and Ling N (1989) Follistatin gene expression in the ovary and extragonadal tissues Molecular Endocrinology 3 651-659

Shukovski L, Findlay J and Robertson D (1991) The effect of folliclestimulating hormone-suppressing protein or follistatin on luteinizing bovine granulosa cells in vitro and its antagonistic effect on the action of activin Endocrinology 126 3395-3402

Sidis Y, Fujiwara T, Leykin L, Issacson K, Toth T and Schneyer A (1998) Characterization of inhibin/activin subunit, activin receptor, and 
follistatin messenger ribonucleic acid in human and mouse oocytes: evidence for activin's paracrine signaling from granulosa cells to oocytes Biology of Reproduction $\mathbf{5 0} 807-812$

Silva CC and Knight PG (1998) Modulatory actions of activin-A and follistatin on the developmental competence of in vitro-matured bovine oocytes Biology of Reproduction 58 558-565

Silva CC, Groome NP and Knight PG (1999) Demonstration of the suppressive effect of inhibin $\alpha$-subunit on the developmental competence of in vitro matured bovine oocytes Journal of Reproduction and Fertility 115 381-388

Smyth CD, Gosden RG, McNeilly AS and Hillier SG (1993) Effect of inhibin immunoneutralisation on steroidogenesis by rat ovarian follicles in vitro. Journal of Endocrinology 140 437-443

Sugino $H$, Nakamura $T$, Hasegawa $Y$, Miyamoto $K$, Abe $Y$, Igarashi $M$, Eto $\mathbf{Y}$, Shibai $\mathbf{H}$ and Titani K (1988) Erythroid differentiation factor can modulate granulosa cell functions Biochemical and Biophysical Research Communications 153 281-288

Tannetta DS, Feist SA, Bleach ECL, Groome NP, Evans LW and Knight PG (1998) Effects of active immunization of sheep against an amino terminal peptide of the inhibin $\alpha \mathrm{C}$ subunit on intrafollicular levels of activin A, inhibin A and follistatin Journal of Endocrinology 157 $157-168$

Tuuri T, Eramaa M, Hilden K and Ritvos O (1994) Activin-binding protein, follistatin messenger ribonucleic acid and secreted protein levels are induced by chorionic gonadotropin in cultured human granulosa-luteal cells Endocrinology 135 2196-2203

Webb R, Campbell BK, Gaverick HA, Gong JG, Gutierrez CG and Armstrong DG (1999) Molecular mechanisms regulating follicular recruitment and selection Journal of Reproduction and Fertility Supplement $\mathbf{5 4}$ 33-48

Webley GE, Marsden PL and Knight PG (1994) Differential control of immunoreactive $\alpha$ inhibin and progesterone production by marmoset luteal cells in vitro: evidence for a paracrine action of $\alpha$ inhibin on basal and gonadotrophin-stimulated progesterone production Biology of Reproduction 50 1394-1402
Woodruff TK (1998) Regulation of cellular and system function by activin Biochemistry and Pharmacology 55 953-963

Woodruff TK (1999) Hope, hypothesis and inhibin receptor. Does specific inhibin binding suggest there is a specific inhibin receptor? Endocrinology $1403-5$

Wrathall JHM and Knight PG (1995) Effects of inhibin-related peptides and oestradiol on androstenedione and progesterone secretion by bovine theca cells in vitro. Journal of Endocrinology 145 491-500

Xiao S, Robertson DM and Findlay JK (1992) Effects of activin and folliclestimulating hormone (FSH)-suppressing protein/follistatin on FSH receptors and differentiation of cultured rat granulosa cells Endocrinology 131 1009-1016

Yamoto M, Minami S and Nakano R (1991) Immunohistochemical localization of inhibin subunits in human corpora lutea during menstrual cycle and pregnancy Journal of Clinical Endocrinology and Metabolism 73 470-477

Yamoto M, Minami S and Nakano R (1992) Immunochemical localization of inhibin/activin subunits in human ovarian follicles during the menstrual cycle Journal of Clinical Endocrinology and Metabolism $\mathbf{7 4}$ 989-993

Ying S (1988) Inhibins, activins and follistatins: gonadal proteins modulating the secretion of follicle-stimulating hormone Endocrine Reviews 9 267-293

*Ying S, Becker A, Ling N, Ueno N and Guillemin R (1986) Inhibin and beta type transforming growth factor (TGF $\beta$ ) have opposite modulating effects on the follicle stimulating hormone (FSH)-induced aromatase activity of cultured rat granulosa cells Biochemical and Biophysical Research Communications 136 969-975

*Ying S-Y, Czvik J, Becker A, Ling N, Ueno N and Guillemin R (1988) Secretion of follicle-stimulating hormone and production of inhibin are reciprocally related Proceedings National Academy of Sciences USA $\mathbf{8 4}$ $4631-4635$

Zimmerman CM and Mathews LS (1996) Activin receptors: cellular signalling by receptor serine kinases Biochemical Society Symposia $\mathbf{6 2}$ 25-38 